\title{
TESTING FOR COMPLETE PASS-THROUGH OF EXCHANGE RATE WITHOUT TRADE BARRIERS
}

\author{
Tengfei ZHANG(D1, Tianxiang LI $^{2 *}$, Tomas BALEŽENTIS ${ }^{(1)}$, \\ Dalia ŠTREIMIKIENE் 3 \\ ${ }^{1}$ Department of Finance, E.J. Ourso College of Business, Louisiana State University, \\ Baton Rouge, USA \\ ${ }^{2}$ College of Economics and Management, Nanjing Agricultural University, \\ Nanjing, P. R. China \\ ${ }^{3}$ Lithuanian Institute of Agrarian Economics, Vilnius, Lithuania
}

Received 02 August 2019; accepted 23 January 2020

\begin{abstract}
The objective of this paper is to test whether the complete pass-through of exchange rate exists when there are almost no transaction costs and in the environment of competitive market. In general, the literature claims that the pass-through of exchange rate is incomplete due to imperfect market, i.e. the presence of transaction costs and imperfect competition. The quasi-experimental case of the food import to Hong Kong from Mainland China is considered in the analysis. The results show that the pass-through of the exchange rate of Chinese RMB against to US dollar to Hong Kong's food import price is complete in long-run equilibrium. Besides, the short-run adjustment significantly contributes to correcting the deviation from the long-run pass-through effect. Moreover, the complete pass-through still exists after accounting for the effects of asymmetry and volatility. Therefore, this paper contributes to the literature by providing empirical evidence that the complete pass-through of exchange rate can exist in the real world.
\end{abstract}

Keywords: pass-through, exchange rate, RMB, quasi-experimental environment, error correction model, quantile regression.

JEL Classification: F31, G18, F42.

\section{Introduction}

From 2005 on, China has gradually reformed its exchange rate regime by switching from fixed exchange rate regime pegged to US dollar towards the floating exchange rate. During that period, the Chinese RMB (renminbi) showed substantial fluctuations. From July 2005 to July 2008 , the RMB appreciated against the US dollar by $21.2 \%$, following a fixed exchange rate of 6.83 RMB/USD up until financial crisis in June 2010. After the crisis, the RMB ap-

*Corresponding author. E-mails: garylee0428@gmail.com; txl0428@njau.edu.cn 
preciated again with larger volatility, and the exchange rate reached the lowest point of 6.05 in January 2014. From 2014 onwards, the exchange rate has increased again and showed even higher volatility rather frequently. Overall, the change in trend is due to China's policy shift to market-based exchange rate regime. However, China's government still has strong power on its foreign exchange market, especially by exploiting its vast foreign exchange reserves to adjust the exchange rate. Therefore, China is still being on the road towards the floating exchange rate regime ( $\mathrm{Li}$ et al., 2015; Hu et al., 2016; Yu \& Xiao, 2017).

High and frequent fluctuations of Chinese RMB not only have effect on China's trade flows, but also impact the price levels in both domestic and foreign markets. This is facilitated via the price transmission of exchange rate in short and medium terms. Even though there has been fluctuation in China's currency exchange rate against many currencies, the exchange rate of RMB against the US dollar is the most crucial one. As long as the US dollar-related transactions account for the largest share of China's foreign currency exchange market, the exchange rate of the RMB against the US dollar plays the key role in China's currency reform.

Hong Kong SAR, even though being a part of People's Republic of China, is a separated market in regards to the Mainland China. According to the policy of "one country, two systems", Hong Kong has its separate currency which is tightly pegged to the US dollar. Consequently, the change in the exchange rate of the RMB against the US dollar would lead to the same change in the rate of China's RMB against the Hong Kong dollar. As the largest offshore market of China's RMB, Hong Kong heavily influences the fluctuation of China's $\mathrm{RMB}$ against the US dollar depending on the situation there.

The exchange rate of China's RMB against Hong Kong dollar is fully determined by the exchange of China's RMB against US dollar, and the Hong Kong's trade is mainly dominated by its imports from the Mainland China (it accounts for more than $80 \%$ of Hong Kong's total import), see China's Custom Statistics (2015). Therefore, the price change of Hong Kong market is largely depended on China's export to Hong Kong and the change of China's RMB against Hong Kong dollar, but not the opposite. As the Mainland China's export to Hong Kong accounts to just a small share of China's agricultural and food product export (less than $2 \%)$, the price level in the Mainland China would not be influenced by Hong Kong's import from Mainland China. Furthermore, there are no tariff barriers or any other trade distortions in regards to the import of Hong Kong from the Mainland China. Therefore, this situation can be considered as an instance of a free trade zone between Hong Kong and Mainland China. In contrast to the long distance trade, the geographical proximity from Hong Kong to Mainland China largely reduced transportation and logistical costs, which usually account for significant share of the total trade costs. Therefore, Hong Kong constitutes a desirable quasi-experiment environment that has no trade cost to estimate the impact of the changes in the exchange rate of RMB against the Hong Kong dollar on the food import price level of Hong Kong without usual considerations about endogeneity. In particular, the food import prices of Hong Kong has little effect on the exchange rate of RMB against Hong Kong dollar, because the Hong Kong dollar is tightly pegged to US dollar and the food import of Hong Kong from Mainland China only accounts for a minimal share of Mainland China's export. Besides, there is no evidence in the literature that the exchange rate of RMB against US dollar is driven by food sector trade between Hong Kong and Mainland China. 
The exchange rate pass-through reflects the reaction of product prices (either import price or domestic price) to changes in exchange rates. Formally, the exchange rate passthrough is measured as the elasticity of import price with respect to the exchange rate. Typically, the elasticity coefficient should be one if there is complete pass-through, otherwise it is incomplete. Existing literature documents that the exchange rate pass-through is incomplete in most countries, industries and products (Menon, 1995; Frankel et al., 2012; Bussiere et al., 2014). Much research on the pass-through of exchange rate is controversial due to the difficulty of specifying trade costs (Bussiere et al., 2014). The imports to Hong Kong from the Mainland China could be a quasi-experiment that has no trade cost (short distance, no tariff, and only one supplier), which allows one to explore the pass-through of exchange rate under the situation of nearly no trade cost. Especially, almost all of Hong Kong' food import originates from the Mainland China, thus the change of RMB against dollar would effectively transmit to Hong Kong's food market. In some extreme cases, steep change in the value of $\mathrm{RMB}$ against the US dollar would lead to large volatility of the prices in food market in Hong Kong. For example, by the statistics on the consumer price index in Hong Kong suggests the price of fresh vegetables (that were mainly imported from the Mainland China) went up by $8.7 \%$ in July 2015, when China started to reform its foreign exchange regime and allowed the exchange rate of RMB to appreciate.

The purpose of the present research is to test for the existence of complete pass-through of exchange rate. The object of the research is pass-through of exchange rate in food imports of Hong Kong from China. The methods used include panel regression (co-integration model and error correction model) and quantile regression. By exploiting the panel data on food imports of Hong Kong from China, this paper proves that the pass-through of exchange rate can be complete after reaching the long-run equilibrium and short-run disequilibrium adjustment, even when accounting for the effects of the asymmetry and volatility. The contribution of this paper is threefold. First, this paper provides the new empirical evidence that the complete pass-through of exchange rate can exist in the real world. In this regard, the food import to Hong Kong from the Mainland China can be used as a novel case to test the theory that the exchange rate pass-through should be complete in the absence of the transaction costs. Second, this paper identifies the mechanism underlying the formation of complete exchange rate pass-through by disentangling the long-run equilibrium and shortrun disequilibrium adjustment. Third, this paper utilizes several econometric methods to estimate the exchange rate pass-through coefficients, with quantile regression used for the first time, to the best of our knowledge, to reflect the exchange rate pass-through at different levels of exchange rate. The paper proceeds as follows. Section 1 presents the literature survey. The estimation approach is discussed in Section 2. Section 3 focuses on the data used. Section 4 brings forward the results.

\section{Literature review}

International trade is related to a number of economic, social an environmental phenomena (Song et al., 2020; Munir \& Ameer, 2018; Yue et al., 2018; S. J. Wang \& L. Wang, 2018; Su et al., 2018; Andrei et al., 2018). A number of papers studied the impacts of trade barri- 
ers (such as trade policies) on relative prices in the domain of international economics. However, nominal exchange rate volatility dominates aggregate trade barriers in explaining common currency relative price volatility (Goldberg \& Knetter, 1997). In other words, the pass-through of exchange rate is a significant factor behind the change in the relative prices. Also, the incomplete pass-through of exchange rate is highly related to the deviation from the exchange rates implied by the Purchasing Power Parity (PPP) which is one of the six unsolved big questions of international finance (Obstfeld \& Rogoff, 2000).

To be clear in regards to terminology, the differences between the pass-through of exchange rate and the transmission of exchange rate should be discussed. Indeed, these concepts mainly relate to the assumption on the market structure. If a monopolistic market is assumed (i.e. a firm sets the price in the market), the pass-through of exchange rate is used. If a competitive market is assumed, the transmission of exchange rate is used. This paper focuses on the pass-through of exchange rate rather than the transmission of exchange rate, which corresponds to much of the literature.

Despite there have been papers on the relations among exchange rates and prices (Chen et al., 2017; Enders et al., 2018), there are still two major unsolved problems, namely the causes of market segmentation and measurement of market power (Goldberg \& Knetter, 1997). The deviation from the Law of One Price is the signal of the market segmentation. There are many friction factors that can lead to deviation of the Law of One Price, such as tariffs, trade impediments, transportation cost and markup etc. Unlike the Law of One Price, the pass-through of exchange rate highly depends on the behavior of exporters where stationarity, co-movement, dynamic adjustment, asymmetry, and competitor prices should be considered. The empirical model of exchange rate pass-through is similar to the model of Law of One Price. However, the relations between Law of One Price and exchange rate pass-through are uncertain unless controlling for the domestic price of exporters. The market power of exporter plays a core role in determining the degree of pass-through of exchange rate. Typically, exporters adjust their premia to offset the risk of volatility of exchange rate, which leads to an incomplete pass-through effect.

It has been shown that the pass-through of exchange rate in developing counties is generally larger than that in developed countries, yet the low pass-through of exchange rates in developing countries has followed a decreasing trend since 1990 (Frankel et al., 2012; Bussiere et al., 2014). Frankel et al. (2012) estimated the pass-through of exchange rate in 76 developing countries and the results showed that the pass-through to import prices is larger than the pass-through to domestic prices and CPI, which suggests that transaction costs are an important factor of pricing-to-market. Such factors as income per capita, distance, tariff, country size, wage level and long-term inflation have significant effect on the magnitude of the coefficient of the pass-through of exchange rate. Empirically, the factors determining the pass-through of exchange rate are still not clear. Brun-Aguerre et al. (2012) showed that inflation, exchange rate volatility, openness and relative wealth are the main drivers of the pass-through of exchange rate in emerging markets, yet did not conclude the same for the output gap and protectionism. Aron, Macdonald, and Muellbauer (2014) documented the conceptual and methodological problems in the studies of exchange rate pass-through in developing and emerging markets. Indeed, they claimed that misspecification is a curial reason 
to obtain unreliable exchange rate pass-through estimation. Chen and $\mathrm{Hu}$ (2019) showed that neural network model can mitigate the misspecification problem and forecast the exchange rate pass-through effect with higher precision.

On the other side, the exchange rate pass-through into consumer prices is lower than into border prices. The exchange rate pass-through into border prices is typically incomplete in the long run, displays dynamics and varies considerably across countries (Burstein \& Gopinath, 2014). Border prices, whatever currency they are set in, respond partially to exchange rate shocks at most empirically estimated horizons. Lower exchange rate pass-through for consumer prices than that for border prices of imported goods can be mechanically explained by the presence of significant local costs that are insensitive to exchange rate movements. Kabundi and Mbelu (2018) showed that the adoption of inflation-targeting regime can reduce the exchange rate pass-through into consumer prices. There is less evidence on the role of variable retail mark-ups in inducing low exchange rate pass-through for consumer prices (Gopinath et al., 2011). An array of micro-level factors have been proposed to explain the incomplete passthrough, such as consumers' habits, consumers' search frictions, exporter-importer's bargaining power, invoice currency choice (Cooke, 2019; Jacob \& Uusküla, 2019; Xu et al., 2019). Some macro factors are also shown to affect the pass-through of exchange rate, such as inflationtargeting regime, foreign-currency debt, and monetary policy credibility (Fendoğlu et al., 2019; Kabundi \& Mbelu, 2018; Kabundi \& Mlachila, 2019; Nguyen \& Sato, 2019).

As the US dollar is the base currency in the international transactions, its exchange rate has high impacts on the dynamics in the commodity prices. Empirical evidence from 51 highly tradable commodities shows that the volatility of commodities is closely related to the US nominal exchange rate (Chen et al., 2014). Since the US dollar accounts for over a half in international payments, the currency invoicing should be considered when estimating the pass-through of exchange rate. Importers and exporters prone to invoice the foreign currency or domestic currency depending on the product market structure and the degree of pass-through of exchange rate (Devereux et al., 2017).

Recently, there have been attempts to explain the causes of incomplete pass-through of exchange rate from the firm level perspective. Rodrìguez-López (2011) presented a stickywage model of exchange rate pass-through with heterogeneous producers and endogenous markups. The model shows that low levels of exchange rate pass-through to firm- and aggregate-level import prices coexist with large movements in trade flows. After an exchange rate shock, aggregate import prices are subject to a composition bias due to changes in the extensive margin of trade (the number of goods traded between countries). At the firm level, each producer adjusts its markups depending on its own productivity and the change in the competitive environment affected by the exchange rate movement. Firm-level price responses are asymmetric - different during appreciations and depreciations - and adjustments in the intensive margin of trade are substantial (Law et al., 2018; Kassi et al., 2019). By using micro-data on sales and prices, Nakamura and Zerom (2010) found that the role of markup adjustment, local costs and menu costs are the three central factors in determining incomplete pass-through of exchange rate. Binding and Dibiasi (2017) used the unexpected change in monetary policy as a natural experiment, thus showing that the uncertainty of change in the exchange rate negatively affects firm investment plans. 
Several recent papers have studied the pass-through of China's exchange rate. Li, Ma, and $\mathrm{Xu}$ (2015) used firm-level data to show that the prices denominated in RMB respond little to the changes in $\mathrm{RMB}$ exchange rate, which indicates there is relatively high exchange rate pass-through into prices denominated in foreign currency. Eichengreen and Tong (2015) examined the impact of the change in the exchange rate of RMB on foreign firms and found that RMB appreciation has no significant effect on the valuation of firms which export to China due to the pattern of processing trade. Processing trade is less affected by exchange rate because these imported product will be exported again after processing, thus the change of exchange rate will not affect this kind of trade too much due to the two-side transaction. From this point of view, the pass-through of exchange rate is also impacted by the industrial structure and trade patterns. Héricourt and Poncet (2013) showed that a trade-deterring effect of RMB exchange rate volatility on the export of China's firms, and the exchange rate risk can be hedged by well-developed financial markets if such exist.

The importance of macroeconomic factors (especially, exchange rates) to agricultural trade had been largely neglected in the literature for many years, possibly due to the microorientation of agricultural economics (Josling et al., 2010). Liefert (2009) summarized the transmission of exchange rate changes to agricultural prices and found that the transmission effect of exchange rate on agricultural prices is low in most developing countries due to extensive trade barriers and inadequate infrastructure. Gervais and Khraief (2007) also showed that the supply constraint of live hogs partly depends on the pass-through of exchange rate in the pork market. Hatzenbuehler, Abbott, and Foster (2016) empirically demonstrated that the key supply-use factors, such as low stocks and policy shifts, would cause larger response of agricultural prices to the change in the exchange rate given to the inelastic market demand. In the short-run, the price transmission is largely decided by the overshooting factors.

In general, the pass-through of exchange rate is proved to be low in developing countries and agricultural markets (Frankel et al., 2012; Hatzenbuehler et al., 2016; Bussière et al., 2014). The reasons are numerous including the trade barriers and market structures (Campa \& Goldberg, 2005; Auer \& Schoenle, 2016). However, there have been no studies to test the pass-through of exchange rate under nearly zero trade cost and competitive market. Thus, this paper addresses the aforementioned issue and thereby addresses the literature gap.

\section{Estimation approach}

Following the Law of One Price, the import price in importer's currency should be equal to the export price in exporter's currency multiplied by the exchange rate of exporter's currency with respect to the importer's currency (the amount of the importer's currency per unit of exporter's currency). For example, if one product such as apples is exported from China to Hong Kong, the import price of the apples in Hong Kong dollars should be equal to the apple price in Chinese RMB times the exchange rate of RMB against Hong Kong dollar (Hong Kong Dollars per Chinese RMB). Therefore, the basic empirical model to be estimated when analyzing the pass-through of exchange rate is as below:

$$
\ln \text { price }_{i t}=\beta_{0}+\beta_{1} \ln \text { market }_{i t}+\beta_{2} \ln \text { china }_{i t}+u_{i t},
$$


where $\ln$ price $_{i t}$ is the logged price of product $i$ that Hong Kong imports from China in Hong Kong dollars at time $t$ (import price); $\ln$ market $_{i t}$ is the logged price of product $i$ in Chinese $\mathrm{RMB}$ at time $t$; $\ln$ china $_{i t}$ is the logged exchange rate of Chinese RMB against the Hong Kong dollar.

If there are zero transaction costs in a competitive market, the coefficients of domestic price and the exchange rate should be equal to unity. However, there exist multiple kinds of transaction costs in international trade, such as tariffs and quotas, sea transport fees, insurance costs alongside distance and other technical trade barriers (Goldberg \& Knetter, 1997; Nakamura \& Zerom, 2010). Moreover, exporters and importers may possess certain degree of market power, thus the pass-through rate could not to be one because the exporters can adjust their premia to keep the price denominated in importer's currency unchanged. Therefore, additional factors should be included into the regression model. Under these circumstances, the pass-through of exchange rate cannot to be complete (that is the rate of the pass-through cannot be equal to one), which has been established in the literature.

Compared with the earlier literature focused on less competitive circumstances, this paper aims to test whether the complete pass-through exists under the quasi-experimental environment. Since China's export to Hong Kong faces no prohibitive trade cost, nearly zero transaction costs, and competitive market, the pass-through of exchange rate should be equal to one. Moreover, since the import to Hong Kong accounts for a negligible share of China's total export, the exchange rate should not be endogenous in the regression. Most importantly, since the Hong Kong dollar is pegged to the US dollar, the change in the value of RMB against the Hong Kong dollar is totally equal to the change of RMB against US dollar, so the exchange rate is an exogenous variable.

Therefore, the first relationship to be tested in this paper is formulated as follows: Under the quasi environment of zero transaction costs and competitive market, the pass-through of exchange rate in the case of China's export to Hong Kong should be complete; that is, the coefficient of exchange rate in Eq. (1) should be equal to one.

Eq. (1) tests the pass-through of exchange rate on the level of import prices, which represents the equilibrium relation between the two variables in the long-run. If this equilibrium relation exists and the pass-through is equal to one, the complete pass-through relation is confirmed. Further test is carried out to check how the equilibrium relation adjusts dynamically from disequilibrium in the short-run. In other words, rather than just focusing on the drivers of the level of import prices, the research also considers the drivers of changes in the import prices. To test the dynamic adjustment in the short-run, the following model is implemented:

$$
D^{D} \ln \text { price }_{i t}=\beta_{0}+\alpha \text { L.error }_{i t}+\beta_{1} \text { D. } \ln \text { market }_{i t}+\beta_{2} D . \ln \text { china }_{i t}+u_{i t},
$$

where D.ln price $_{i t}$ is the first difference of the logged price of the product $i$ that Hong Kong imports from China at time period $t$; L.error $_{i t}$ is the lag of estimated error from Eq. (1), which shows the adjustment relations in the short-run disequilibrium; $D . \ln$ market $_{i t}$ is the first difference of the logged price of product $i$ in China's domestic market at time period $t$; D. ln china ${ }_{i t}$ is the first difference of the logged exchange rate of RMB against the Hong Kong dollar. 
The long-term relationship between prices and exchange rates is rather persistent. The short-run case is indeed more important for analysis of market behavior, because it allows looking at the adjustment process of prices changes after an exchange rate shock. Based on model given in Eq. (2), the second relationship is formulated as follows: Under the quasi-experimental environment of zero transaction costs and competitive market, the pass-through of exchange rate in China's export to Hong Kong should be complete and exhibit significant adjustment process in the short-run. That is to say, the coefficient of exchange rate in Eq. (2) should be equal to one and the coefficient of the lagged residual should be significant.

\section{Data used}

Since food markets are generally considered as perfectly competitive ones, this research covers 11 kinds of agricultural and food products which are exported from Mainland China to Hong Kong. Given the data availability, the products covered include: rice, wheat flour, peanut kernels, rape oil, hogs, pork, sheep, chicken, tomatoes, green bell pepper, and apples. The Mainland China is the most important exporter of these products to Hong Kong (more than 90 per cent of the total imports). Furthermore, more than 90 per cent of these products are imported to Hong Kong. The import price is calculated by dividing the import value by import volume. The data on import values and import volumes come from China's Custom Statistics. China's domestic price data come from the Yearbook of China's Agricultural Prices.

The exchange rate data are taken from St. Louis Federal Reserve on-line database. Hong Kong dollar is pegged to US dollar, thus the paper uses the change of the value of RMB against US dollar to reflect the change of the value of RMB against Hong Kong dollar. To reflect the change of RMB against US dollar, the direct quotation of exchange rate is used, i.e. the amount of US dollars per one Chinese Yuan, where Chinese Yuan is fixed currency, and US dollar is variable currency. For example, the exchange rate of 0.165 in January 2014 means 0.165 dollar equals to one Chinese Yuan. The monthly exchange rate data from Federal Reserve is calculated as the average of daily noon buying rates in New York City for cable transfers payable in foreign currencies within each month. These data are slightly different from the statistics provided by China's State Administration of Foreign Exchange (SAFE) since they are collected in different marketplaces. The data from SAFE were also used and almost identical results were obtained, thus the conclusions are robust to data sources. Existing literature, such as Goldberg (2004), suggests using industry-specific effective exchange rate to capture heterogeneity in competitive conditions across industries, especially when analyzing exchange rate pass-through at the aggregate level (country level or industry level). However, weighted exchange rates contain endogeneity issue because trade weights contain price information, and this problem is more severe when estimating exchange rate pass-through at the product level. This paper also studies the exchange rate pass through at the product level, specifically, 11 products in the same sector, namely agricultural industry. Therefore, this paper applies bilateral nominal exchange rate, which is proposed by Gaulier et al. (2008).

The time range covered is from 2007 to 2014. The data description is given in Table 1 . Note that the data for the rape oil only cover years 2007-2012. Accordingly, variable lnmarket 
has 24 observations less than the other two variables. The choice of the period covered is subject to data availability. Indeed, there have been no serious economic turbulences since 2014 which would be neglected in the analysis.

Table 1. Descriptive statistics of the main variables

\begin{tabular}{|c|c|c|c|c|c|}
\hline Variable & Obs & Mean & Std. Dev. & Min & Max \\
\hline $\ln$ price 2 & 1056 & 0.0386 & 1.130 & -2.240 & 2.377 \\
\hline $\ln$ market & 1032 & 2.214 & 0.817 & 0.7129 & 4.192 \\
\hline $\ln$ china 1 & 1056 & -1.893 & 0.0687 & -2.053 & -1.800 \\
\hline
\end{tabular}

\section{Results and discussion}

The empirical analysis comprises the four parts. First, the test for the existence of the panel unit root and co-integration among the three variables defining exchange rate pass-through is carried out (Section 4.1). Second, regression analysis is performed to test if there exists a complete pass-through, in terms of both long-run equilibrium relations and short-run adjustment (Sections 4.2 and 4.3). Third, the asymmetry and volatility on the pass-through of exchange rate are analyzed (Sections 4.4 and 4.5). Finally, the sensitivity of the pass-through coefficients of the level and difference models is tested across different quantiles (Sections 4.6 and 4.7). The use of the quantile regression models allows one to check the pass through at different import price levels.

\subsection{Unit root test and co-integration test}

In order to check the stationarity of the variables used in the modelling, three tests - LevinLin-Chu test, Im-Pesaran-Shin test, and augmented Dickey-Fuller test - are applied for the panel data (lnprice2 and lnmarket) and three - augmented Dickey-Fuller test, Dickey-Fuller test with generalized least squares transformation (DFGLS), and Kwiatkowski-PhillipsSchmidt-Shin (KPSS) test - are applied for the time series data (lnchina). These tests are commonly used to examine the stationarity of the panel data and help to select the proper variable transformations and models (Baltagi, 2008). The panel data are demeaned using cross-section means to control for cross-sectional dependence. For both panel and time series data, trend is allowed for and removed in case it appears to be insignificant and control for autocorrelation by including the lag terms.

The panel unit root tests in Table 2 show that at least two variables are non-stationary. For variable $\ln p r i c e 2$, the two tests fail to reject the null hypothesis of unit roots $(p>0.05)$, which means the variable is non-stationary in the panel data. Turning to variable lnmarket, one can implement two tests only as the Levin-Lin-Chu test requires the balanced data. In this case, Im-Pesaran-Shin test and the augmented Dickey-Fuller test reject the null hypothesis of nonstationarity $(p<0.05)$. All the three tests show that variable lnchina is non-stationary. These results imply that all the three variables are probably not integrated of order 0 . Therefore, test for co-integration among these variables will be applied. 
Table 2. Panel unit root tests for the main variables

\begin{tabular}{|c|c|c|c|c|c|}
\hline Variables & $\begin{array}{c}\text { Levin-Lin-Chu } \\
\text { test }\end{array}$ & $\begin{array}{c}\text { Im-Pesaran- } \\
\text { Shin test }\end{array}$ & $\begin{array}{c}\text { Augmented } \\
\text { Dickey-Fuller test }\end{array}$ & DFGLS test & KPSS test \\
\hline $\ln$ price2 & 0.855 & 0.025 & 0.083 & - & - \\
\hline $\ln$ market & - & 0.000 & 0.000 & - & - \\
\hline $\ln$ china1 & - & - & 0.092 & $>0.050$ & $<0.050$ \\
\hline
\end{tabular}

Note: $p$-values are given for the null hypothesis of unit roots (for KPSS test, the null hypothesis is stationarity).

The test for co-integration delivers the same conclusion, too. Specifically, following Westerlund (2007), the Westerlund test is applied as an error-correction-based co-integration test for panel data. The error-correction test evaluates the speed at which the relationship among the dependent variable and independent variables corrects back to equilibrium relationship after a sudden shock. The error-correction coefficient should be significantly negative if there is co-integration. Table 3 provides four tests for the error-correction coefficient. The results in Table 3 show that all the coefficients are negative and test statistics are highly significant, which means that there is a co-integration relation among the export price, the domestic price and the exchange rate.

Table 3. Westerlund ECM-based co-integration tests for the main variables

\begin{tabular}{|c|c|c|c|}
\hline Statistic & Value & $Z$-value & $P$-value \\
\hline$G t$ & -4.131 & -7.547 & 0.000 \\
\hline$G a$ & -29.697 & -10.878 & 0.000 \\
\hline$P t$ & -10.412 & -4.581 & 0.000 \\
\hline$P a$ & -19.702 & -8.207 & 0.000 \\
\hline
\end{tabular}

Note: $\mathrm{Gt}$ and $\mathrm{Ga}$ are statistics of the group-mean tests across individual cross-sectional units. $\mathrm{Pt}$ and $\mathrm{Pa}$ are statistics of the panel tests (see detail description in Persyn \& Westerlund, 2008).

\subsection{Equilibrium relations in the long-run: co-integration model}

The relations among the level of domestic prices, exchange rate and import prices are checked. In the model estimated, the domestic price (lnmarket) and the exchange rate (lnchina1) are regressed on the import price (lnprice2). Furthermore, the time trend is added to de-trend the variables. Three types of models are implemented: the fixed effects, the random effects, and MLE (Maximum likelihood estimation). The estimates of the co-integration regressions are shown in Table 4. The results are robust to the choice of the model in terms of the estimates of the coefficients of interest. All the variables are significant, and have the expected signs. The Durbin-Hausman-Wu test shows that the fixed effects model can be used.

As suggested by the results of the fixed effects model, the coefficient of exchange rate is 0.980 , and it is significant at the level of 5\%. The t-test shows that the coefficient is not significantly different from one, which implies the first relationship (see Section 3) is not rejected. Therefore, one might claim that the price of Hong Kong imports from China would increase 
$1 \%$ if the China's RMB appreciates almost $1 \%$ against Hong Kong (or US dollar) dollar in the long-run. There are several reasons behind this, such as low transportation cost, low trade barriers. The transportation cost from the Mainland China to Hong Kong is low, not only because of the geographic proximity, but also because of the developed infrastructure such as efficient railways, highways, and convenient custom clearance procedures. Besides, there are no tariff-based or any other policy limitations on food trade between the Mainland China and Hong Kong, which rare in effect in regards to the other trade counterparts. The complete pass-through of China's RMB against Hong Kong dollar to Hong Kong's food import price provides strong evidence that the implicit assumption that the pass-through in emerging markets is low can be wrong. Even though the previous research generally suggested that weak pass-through in developing countries is due to the high transportation costs and trade barriers there, the situations with no transportation costs and trade barriers were not considered. Therefore, this paper complements the literature by discussing a case where complete pass-through can exist in real world, and, under certain conditions, the evidence is found to support the law of one price.

The coefficients of the control variables are consistent to expectation as well. The domestic price and time trend variables are significant too and have the positive coefficients. If the China's domestic food price increases $1 \%$, the food price of Hong Kong imported from Mainland China would go up by $0.454 \%$. Corresponding to the trend of increasing food prices both in the Mainland China and Hong Kong, the food import price increases by 0.3 per cent each month on average. The coefficient of determination is 0.56 for the fixed effects model, which means the model has relatively reasonable specification and large explanatory power in regards to the price change of the food import to Hong Kong from the Mainland China.

Table 4. Results of the exchange rate pass-through model in the long-run

\begin{tabular}{|c|c|c|c|}
\hline \multirow{2}{*}{ Dependent var. } & 1 - Fixed Effects & 2 - Random Effects & 3 - MLE \\
\cline { 2 - 4 } & $\ln p$ rice2 & $\ln$ price 2 & $\ln$ price 2 \\
\hline \multirow{2}{*}{$\ln$ market } & $0.454^{* * *}$ & $0.484^{* * *}$ & $0.469^{* * *}$ \\
\cline { 2 - 4 } & $(0.042)$ & $(0.042)$ & $(0.042)$ \\
\hline \multirow{2}{*}{$\ln$ china1 } & $0.980^{* *}$ & $0.931^{* *}$ & $0.954^{* *}$ \\
\cline { 2 - 4 } & $(0.320)$ & $(0.321)$ & $(0.319)$ \\
\hline \multirow{2}{*}{ time } & $0.003^{* * *}$ & $0.003^{* * *}$ & $0.003^{* * *}$ \\
\cline { 2 - 4 } & $(0.001)$ & $(0.001)$ & $(0.001)$ \\
\hline \multirow{2}{*}{ cons } & -1.058 & -1.168 & -1.112 \\
\hline$N$ & $(1.067)$ & $(1.085)$ & $1.090)$ \\
\hline$R^{2}$ & 1032 & 1032 & 82.748 \\
\hline Log. likelihood & 0.560 & & \\
\hline \multirow{2}{*}{ D-W-H test } & 127.394 & 13.380 & \\
\hline
\end{tabular}

Notes: standard errors are given in parentheses; significance codes: ${ }^{*} p<0.05,{ }^{* *} p<0.01,{ }^{* * *} p<0.001$; $\mathrm{D}-\mathrm{W}-\mathrm{H}$ stands for the Durbin-Hausman-Wu test. 


\subsection{Adjustment relations in the short-run: error correction model}

To examine validity of the second relationship (see Section 3), the paper further looks into the short-run adjustment in the context of the exchange rate pass-through model in Table 5. In the initial model, the new variable is the lagged residual of the fixed effects panel model (the first column in Table 4) along with other control variables (such as the lag of first difference of logged domestic price, LD.lnmarket). The first model corresponds to that given by Eq. (2). Contrary to our expectations, the coefficient of D.lnchinal is insignificant. The signs of all the variables are as expected.

The residual from the preceding period has a negative and statistically significant effect on the change of import price, which indicates the short-run adjustment effect exists. Since the exchange rate has positive effect on the import price, the error adjustment term should be negative in the dynamic adjustment model. If the import price in the preceding period is too high, the adjustment process would lead to a decrease in the growth rate of the import price in the current period. The result in column (1) of Table 5 shows that the adjustment coefficient is $-0.24 \%$, which means the long-run equilibrium between exchange rate and import price is corrected gradually through a short-run adjustment with a speed of $24 \%$. For instance, if the model predicts import price change to be 1 percent higher than the equilibrium level in the preceding month, then the short-term adjustment mechanism

Table 5. Results of the exchange rate pass-through model in the short-run

\begin{tabular}{|c|c|c|c|}
\hline \multirow{2}{*}{ Dependent var. } & (1) & (2) & (3) \\
\hline & D.lnprice 2 & D.lnprice2 & D.lnprice 2 \\
\hline \multirow{2}{*}{ L.error } & $-0.240^{* *}$ & $-0.193^{* * *}$ & $-0.191^{* * *}$ \\
\hline & $(0.058)$ & $(0.040)$ & $(0.038)$ \\
\hline \multirow{2}{*}{ D.lnmarket } & $0.187^{* *}$ & $0.192^{* * *}$ & $0.178^{* *}$ \\
\hline & $(0.042)$ & $(0.042)$ & $(0.050)$ \\
\hline \multirow{2}{*}{ D.lnchina 1} & 0.319 & 0.593 & -0.050 \\
\hline & $(1.236)$ & $(1.194)$ & $(1.331)$ \\
\hline \multirow{2}{*}{ LD.lnmarket } & & & 0.035 \\
\hline & & & $(0.074)$ \\
\hline \multirow{2}{*}{ LD.lnchina 1} & & & 1.188 \\
\hline & & & $(0.662)$ \\
\hline \multirow{2}{*}{ LD.lnprice 2} & & $-0.200^{* * *}$ & $-0.202^{* \star \star}$ \\
\hline & & $(0.042)$ & $(0.043)$ \\
\hline \multirow{2}{*}{ _cons } & 0.005 & 0.005 & 0.004 \\
\hline & $(0.003)$ & $(0.003)$ & $(0.003)$ \\
\hline $\mathrm{N}$ & 1021 & 1010 & 1010 \\
\hline$R^{2}$ & 0.121 & 0.160 & 0.162 \\
\hline Log. likelihood & 551.056 & 570.641 & 571.398 \\
\hline
\end{tabular}

Notes: standard errors are given in parentheses; significance codes: ${ }^{*} p<0.05,{ }^{* *} p<0.01,{ }^{* * *} p<0.001$; $D$ and $L$ denote the difference and lag operators, respectively. 
would correct this deviation, and decrease the import price change by 0.24 percent. Besides, the growth of domestic price and appreciation of China's RMB would lead to higher growth rate of the import price. The second and third columns in Table 5 show similar results after controlling for some control variables. Therefore, the results are robust to alternative specifications of the dynamic adjustment models.

\subsection{Asymmetry effect}

Much literature has emphasized the existence of the asymmetry effect for the pass-through of exchange rate, which implies that depreciation and appreciation of a currency might induce different pass-through coefficients (Delatte \& Lopez, 2012; Bussiere, 2013). However, the results obtained (Table 6) indicate there is no asymmetry effect in our case. A dummy variable is introduced in the fixed effects co-integration model, achina, which obtains value of 1 in case of appreciation and 0 in case of depreciation. Then, the dummy variable is interacted with the exchange rate (i.achina\#c.lnchina1). However, further results indicate that the interaction term is insignificant and has little impact on the coefficient of the pass-through. These findings are reasonable in that the appreciation and depreciation of exchange rate should induce the same pass-through elasticity in a competitive market as no export firm has market power to adjust the market price and premium.

Table 6. The exchange rate pass-through model with the asymmetry effect

\begin{tabular}{|c|c|}
\hline Dependent var. & $\ln$ price2 \\
\hline \multirow{2}{*}{$\ln$ market } & $0.460^{* * *}$ \\
\cline { 2 - 2 } & $(0.043)$ \\
\hline \multirow{2}{*}{$\ln$ china1 } & $0.946^{* *}$ \\
\cline { 2 - 2 } & $(0.321)$ \\
\hline \multirow{2}{*}{ i.achina\#c.lnchina1 } & -0.012 \\
\cline { 2 - 2 } & $(0.009)$ \\
\hline \multirow{2}{*}{ time } & $0.003^{* * *}$ \\
\cline { 2 - 2 } & $(0.001)$ \\
\hline \multirow{2}{*}{ cons } & -1.142 \\
\hline $\mathrm{N}$ & $(1.068)$ \\
\hline$R^{2}$ & 1032 \\
\hline $\mathrm{F}$ & 0.561 \\
\hline Log. likelihood & 325.210 \\
\hline
\end{tabular}

Notes: standard errors are given in parentheses; significance codes: ${ }^{*} p<0.05,{ }^{* *} p<0.01,{ }^{* * *} p<0.001$. Note that, for the variable "i.achina\#c.lnchina1", "i" indicates a dummy variable, "c" indicates a continuous variable and "\#" represents multiplication in this paper.

\subsection{Volatility effect}

High volatility of the exchange rate may induce different pass-through coefficient if contrasted with the case of low volatility of the exchange rate (Corsetti et al., 2008). We, thus, con- 
struct a dummy variable, $e c$, which gets the value of 1 in case the change in the exchange rate is two times higher than the mean change in the exchange rate of the China's RMB against the Hong Kong dollar, and is to be zero otherwise. Then, the fixed effects co-integration model with the interaction term between the dummy variable and the exchange rate, i.ec\#c. lnchina1, is estimated. Table 7 shows that the interaction term has a negative sign, which means that high volatility would reduce the pass-through coefficient. However, the associated coefficient is insignificant, thus one cannot conclude that high volatility of the exchange rate would increase or decrease the pass-through coefficient. Indeed, the pass-through coefficient of exchange rate does not change substantially and still remains not significantly indifferent from one, which once again confirms the existence of the complete pass-through.

Table 7. The exchange rate pass-through model with the volatility effect

\begin{tabular}{|c|c|}
\hline Dependent var. & $\ln$ price 2 \\
\hline \multirow{2}{*}{$\ln$ market } & $0.451^{* * *}$ \\
\hline & $(0.043)$ \\
\hline \multirow{2}{*}{$\operatorname{lnchina1}$} & $1.047^{* * *}$ \\
\hline & $(0.331)$ \\
\hline \multirow{2}{*}{ i.ec\#c.lnchina 1} & -0.012 \\
\hline & $(0.015)$ \\
\hline \multirow{2}{*}{ time } & $0.003^{* * *}$ \\
\hline & $(0.001)$ \\
\hline \multirow{2}{*}{ _cons } & -0.843 \\
\hline & $(1.100)$ \\
\hline$N$ & 1032 \\
\hline$R^{2}$ & 0.690 \\
\hline $\mathrm{F}$ & 542.010 \\
\hline Log. likelihood & 131.267 \\
\hline
\end{tabular}

Notes: standard errors are given in parentheses; significance codes: ${ }^{*} p<0.05,{ }^{* *} p<0.01,{ }^{* * *} p<0.001$.

\subsection{Exchange rate pass-through across the quantiles}

To check the sensitivity of the pass-through coefficient of the exchange rate at different levels of the exchange rate, the quantile regression is applied when estimating Eq. (1) by using cointegration model with fixed effects. The bootstrap-based analysis (Table 8) shows the passthrough coefficient changes largely across different quantiles - even from negative values to positive ones. The F-test rejects the null hypothesis that the pass-through coefficients in the five quantiles are equal $(p<0.05)$. At the $10^{\text {th }}$ quantile, when the exchange rate (USD/RMB) is relatively low, the coefficient even becomes negative. This is especially topical for period around year 2005, when China started to reform its exchange rate regime. Besides, the market conditions were more stringent and transportation costs were higher than compared 
to situation in the recent years. At the quantiles above the $50^{\text {th }}$, the pass-through coefficient becomes positive, and especially, the coefficient gets closer to the value of one around the $75^{\text {th }}$ quantile.

Table 8. Results of quantile regressions on the long-run exchange rate pass-through model

\begin{tabular}{|c|c|c|c|c|c|}
\hline \multirow{2}{*}{ Dependent var. } & $1-\mathrm{q} 10$ & $2-\mathrm{q} 25$ & $3-\mathrm{q} 50$ & $4-\mathrm{q} 75$ & $5-\mathrm{q} 90$ \\
\cline { 2 - 6 } & $\ln$ price 2 & $\ln$ price 2 & $\ln$ price 2 & $\ln$ price 2 & $\ln$ price 2 \\
\hline \multirow{2}{*}{$\ln$ market } & $1.589^{* * *}$ & $1.442^{* * *}$ & $1.082^{* * *}$ & $0.980^{* * *}$ & $0.970^{* * *}$ \\
\cline { 2 - 6 } & $(0.022)$ & $(0.019)$ & $(0.034)$ & $(0.009)$ & $(0.011)$ \\
\hline \multirow{2}{*}{$\ln$ china1 } & $-1.836^{* * *}$ & -0.530 & $0.549^{* *}$ & $1.030^{* * *}$ & $1.075^{* * *}$ \\
\cline { 2 - 6 } & $(0.270)$ & $(0.351)$ & $(0.185)$ & $(0.119)$ & $(0.113)$ \\
\hline \multirow{2}{*}{ cons } & $-7.650^{* * *}$ & $-4.517^{* * *}$ & $-1.161^{* *}$ & 0.193 & 0.418 \\
\cline { 2 - 6 } & $(0.539)$ & $(0.679)$ & $(0.406)$ & $(0.216)$ & 1016 \\
\hline N & 1016 & 1016 & 1016 & 1016 & \\
\hline \multirow{2}{*}{ F-test } & 33.590 & & & & \\
\hline
\end{tabular}

Notes: standard errors are given in parentheses; significance codes: ${ }^{*} p<0.05,{ }^{* *} p<0.01,{ }^{* * *} p<0.001$.

For sake of clarity, Figure 1 shows the change in the pass-through coefficient across all the quantiles. This indicates that the pass-through coefficient increases as the quantile order goes up and keeps stable after 0.55 quantile. For the higher order quantiles, one can see the pass-through coefficient is about one, which implies complete pass-through. However, for the lower quantiles, the pass-through coefficients increase from negative values to positive ones. Generally, the quantiles mostly coincide with the time trend, since the exchange rate of RMB against the US dollar had been appreciating from 2005 to 2014. Therefore, one can conclude that the pass-through coefficient showed an upward trend for the period of 2004-2015. This

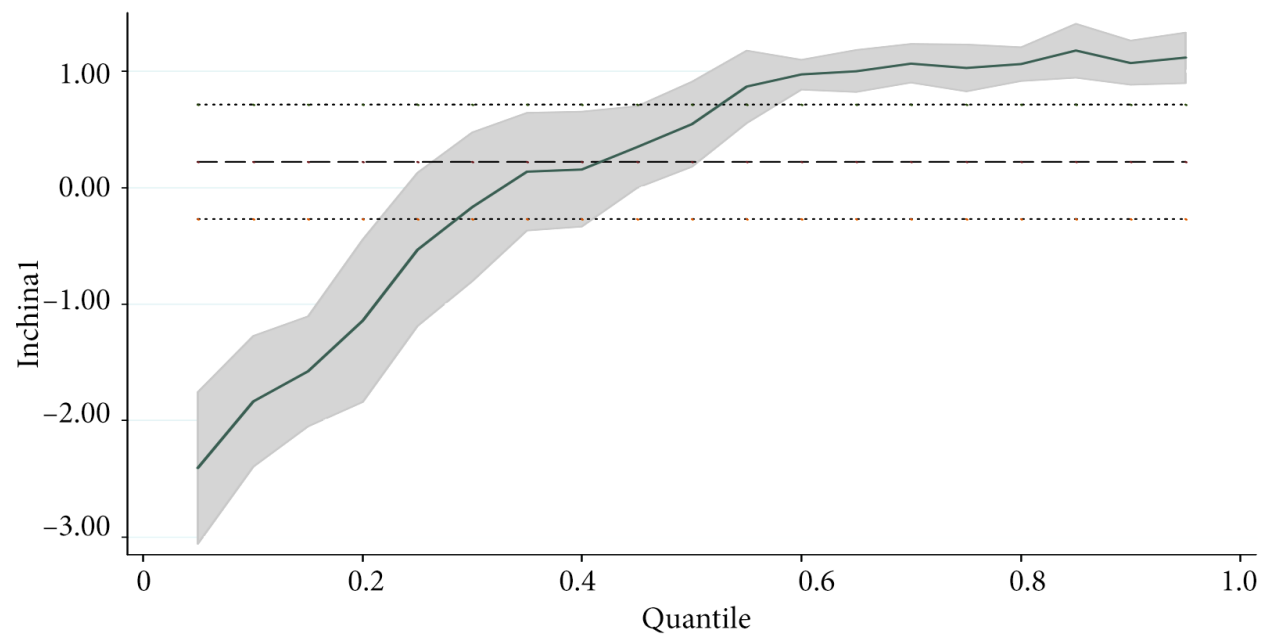

Figure 1. The pass-through coefficients from the quantile regressions of long-run equilibrium model 
also implies that the gradual improvement of market conditions due to infrastructure development and policy interventions has reduced trade costs along the time.

Table 9 presents the results of the short-run dynamic adjustment model across the five quantiles based on the bootstrap approach. The results are more stable across different quantiles if compared to the case of the co-integration model (Table 8). The coefficients of the short-run adjustment term (error1) are all negative and significant. The coefficients of the pass-through of exchange rate vary across different quantiles, and the significances differ as well. However, the F-test shows that one cannot reject the hypothesis that the pass-through coefficients for the five quantiles are equal. Figure 2 shows the pass-through coefficients across all quantiles for the model. The pass-through coefficients are similar to the mean value of some 1.50 across the quantiles, yet the divergence appears for the lowest and highest quantiles. Obviously, some extreme observations influence the values of the estimates in the critical quantiles. From the economic perspective, some extreme events may occur (such as shock due to Bird Flu), which can lead to steep changes to import prices, but these factors are not included into the model. However, it was showed that there was no asymmetry effect and volatility effect in Sections 4.5 and 4.6. Thus, one cannot conclude that the differences of pass-through coefficients across quantiles are due to these two effects.

Table 9. Results of the quantile regressions on the short-run exchange rate pass-through model

\begin{tabular}{|c|c|c|c|c|c|}
\hline \multirow{4}{*}{ errorl } & $1-\mathrm{q} 10$ & $2-\mathrm{q} 25$ & $3-\mathrm{q} 50$ & $4-\mathrm{q} 75$ & $5-\mathrm{q} 90$ \\
\cline { 2 - 6 } & $\ln$ price2d & $\ln$ price2d & $\ln$ price2d & $\ln$ price $2 \mathrm{~d}$ & $\ln$ price2d \\
\cline { 2 - 6 } & $-0.292^{* * *}$ & $-0.210^{* * *}$ & $-0.109^{* * *}$ & $-0.104^{* * *}$ & $-0.161^{* *}$ \\
\hline \multirow{3}{*}{$\ln$ marketd } & $0.051)$ & $(0.035)$ & $(0.029)$ & $(0.026)$ & $(0.049)$ \\
\cline { 2 - 6 } & 0.149 & $0.148^{* * *}$ & 0.081 & 0.104 & 0.104 \\
\hline \multirow{2}{*}{$\ln$ china1d } & $(0.076)$ & $(0.044)$ & $(0.065)$ & $(0.071)$ & $(0.161)$ \\
\cline { 2 - 6 } $\ln$ price2dl & 1.303 & $1.618^{*}$ & $1.332^{* *}$ & 1.111 & $1.741^{*}$ \\
\cline { 2 - 6 } & $(0.790)$ & $(0.658)$ & $(0.404)$ & $(0.610)$ & $(0.808)$ \\
\hline \multirow{2}{*}{ cons } & $-0.290^{*}$ & $-0.214^{*}$ & $-0.149^{*}$ & $-0.122^{*}$ & -0.092 \\
\cline { 2 - 6 } & $(0.119)$ & $(0.097)$ & $(0.059)$ & $(0.056)$ & $(0.064)$ \\
\hline \multirow{2}{*}{$N$} & $-0.140^{* *}$ & $-0.051^{* *}$ & 0.022 & $0.089^{* * *}$ & $0.115^{* * *}$ \\
\hline \multirow{2}{*}{ F-test } & $(0.049)$ & $(0.019)$ & $(0.014)$ & $(0.010)$ & $(0.014)$ \\
\hline & 1016 & 1016 & 1016 & 1016 & 1016 \\
\hline
\end{tabular}

Notes: standard errors are given in parentheses; significance codes: ${ }^{*} p<0.05,{ }^{* *} p<0.01,{ }^{* *} p<0.001$.

The results of the quantile regression differ much with the results in Table 5, where the pass-through coefficient was much lower and insignificant. Since the quantile regression is implemented along with bootstrap of 100 replications, it is reasonable to assume its results are more robust than the mean estimates in Table 5. Hence, it can be concluded that the pass-through of exchange rate is significant and the transmission is approximately complete in the short run. 


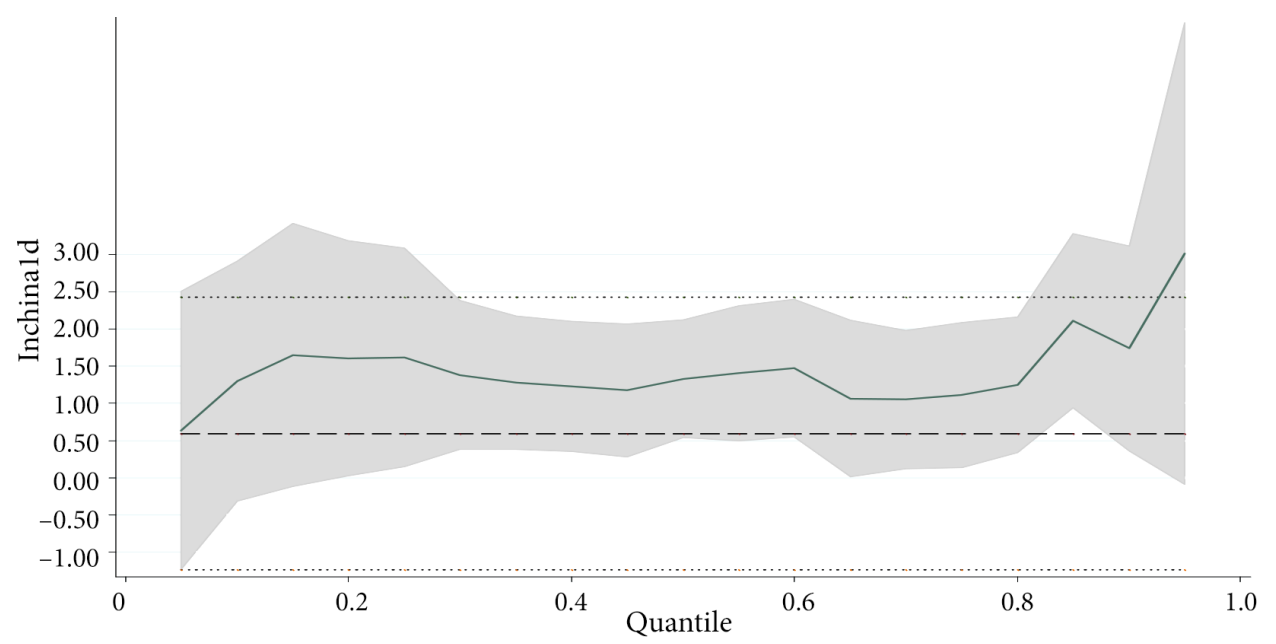

Figure 2. The pass-through coefficients from the quantile regression of short-run dynamic adjustment model

\section{Conclusions}

Much of the previous literature argues that the pass-through of exchange rate is incomplete due to imperfect market such as transaction costs and imperfect competition. By exploiting the quasi-experimental environment in the case of food import to Hong Kong from the Mainland China, this paper tests whether the complete pass-through of exchange rate occurs when there are no transaction costs and competitive market exists. The results show that the pass-through of exchange rate is complete in the long-run. Furthermore, disequilibrium adjustment in the short-run was found. The same results are obtained after accounting for the effects of the asymmetry and volatility. Consistent with theoretical reasoning, this paper implies that competitive market environment without trade costs can induce complete pass-through of exchange rate into import or export prices. The finding is consistent to the phenomenon of the imported inflation where the large volatility of exchange rate triggers fluctuations in import prices and, eventually, in consumer price index. For example, Hong Kong heavily relies on food import from Mainland China. Therefore, steep depreciation of local currency can induce severe imported inflation. As the low-income households show higher shares of food expenditure in their consumption structure, the complete exchange pass-through will definitely have higher impact on these households. Accordingly, concerns on the welfare distribution across households should be taken into consideration when making decisions on the exchange rate and setting the targets for the monetary policy. Besides, the strong co-movement of exchange rate and price level can undermine macroeconomic stability in general.

The framework used in this paper features certain limitations. This paper only considered the three main variables in the empirical model and ignored the other variables that potentially have impact on the pass-through of exchange rate and the import price. These 
variables could be, e.g., macroeconomic variables like relative GDP and inflation level. Such factors should be considered in the future research.

\section{Acknowledgements}

The corresponding author gratefully thanks the financial support from the National Science Foundation of China (Project No. 71934005, 71803085, 71773051 and 71673142 ), the China Postdoctoral Science Foundation (No. 2017M621766) and the Postdoctoral Research Funding Scheme of Jiangsu Province (2018K066B). Support from Priority Academic Program Development (PAPD) of Jiangsu Higher Education Institutions, China Center for Food Security Studies, Jiangsu Center for Food Security Studies is also acknowledged.

\section{Author contributions}

Tengfei Zhang and Tianxiang Li proposed the research idea and Tengfei Zhang wrote the first draft. Tengfei Zhang, Tianxiang Li and Tomas Baležentis worked on the analysis, interpretation of results and discussion, structured and revised the paper at a large scale. The further revision work was carried out by Dalia Streimikiene. Tomas Baležentis made the final proof corrections. All the authors have read and approved the final manuscript.

\section{Disclosure statement}

The authors have declared no conflicts of interest in this paper.

\section{References}

Andrei, J., Zaharia, M., \& Drăgoi, M. C. (2018). Impact of the main currencies exchange rates on the Romanian economic policy transformation. Montenegrin Journal of Economics, 14(3), 7-20. https://doi.org/10.14254/1800-5845/2018.14-2.1

Aron, J., Macdonald, R., \& Muellbauer, J. (2014). Exchange rate pass-through in developing and emerging markets: A survey of conceptual, methodological and policy issues, and selected empirical findings. Journal of Development Studies, 50(1), 101-143. https://doi.org/10.1080/00220388.2013.847180

Auer, R. A., \& Schoenle, R. S. (2016). Market structure and exchange rate pass-through. Journal of International Economics, 98, 60-77. https://doi.org/10.1016/j.jinteco.2015.10.003

Baltagi, B. (2008). Econometric analysis of panel data. John Wiley \& Sons.

Binding, G., \& Dibiasi, A. (2017). Exchange rate uncertainty and firm investment plans evidence from Swiss survey data. Journal of Macroeconomics, 51, 1-27. https://doi.org/10.1016/j.jmacro.2016.11.004

Brun-Aguerre, R., Fuertes, A. M., \& Phylaktis, K. (2012). Country and time variation in import passthrough: What drives it? Journal of International Money \& Finance, 31(4), 818-844. https://doi.org/10.1016/j.jimonfin.2012.01.009

Burstein, A., \& Gopinath, G. (2014). International prices and exchange rates. Handbook of International Economics (Vol. 4, pp. 391-451). Elsevier B.V. https://doi.org/10.1016/B978-0-444-54314-1.00007-0

Bussiere, M. (2013). Exchange rate pass-through to trade prices: The role of nonlinearities and asymmetries. Oxford Bulletin of Economics and Statistics, 75(5), 731-758.

https://doi.org/10.1111/j.1468-0084.2012.00711.x 
Bussière, M., Chiaie, S. D., \& Peltonen, T. A. (2014). Exchange rate pass-through in the global economy: The role of emerging market economies. IMF Economic Review, 62(1), 146-178. https://doi.org/10.1057/imfer.2014.5

Campa, J. M., \& Goldberg, L. S. (2005). Exchange rate pass-through into import prices. Review of Economics and Statistics, 87(4), 679-690. https://doi.org/10.1162/003465305775098189

Chen, H., \& Hu, W. (2019). Research on exchange rate pass-through effect based on artificial intelligence approach. Concurrency and Computation: Practice and Experience, 31(9), e4986. https://doi.org/10.1002/cpe.4986

Chen, S. L., Jackson, J. D., Kim, H., \& Resiandini, P. (2014). What drives commodity prices? American Journal of Agricultural Economics, 5(6), 1455-1468. https://doi.org/10.1093/ajae/aau014

Chen, Z., Devereux, M. B., \& Lapham, B. (2017). The Canadian border and the US dollar: The impact of exchange rate changes on US retailers. Canadian Journal of Economics, 50(5), 1525-1555. https://doi.org/10.1111/caje.12306

Cooke, D. (2019). Consumer search, incomplete exchange rate pass-through, and optimal interest rate policy. Journal of Money, Credit and Banking, 51(2-3), 455-484. https://doi.org/10.1111/jmcb.12518

Corsetti, G., Dedola, L., \& Leduc, S. (2008). High exchange-rate volatility and low pass-through. Journal of Monetary Economics, 55(6), 1113-1128. https://doi.org/10.1016/j.jmoneco.2008.05.013

Delatte, A. L., \& López-Villavicencio, A. (2012). Asymmetric exchange rate pass-through: Evidence from major countries. Journal of Macroeconomics, 34(3), 833-844. https://doi.org/10.1016/j.jmacro.2012.03.003

Devereux, M. B., Dong, W., \& Tomlin, B. (2017). Importers and exporters in exchange rate pass-through and currency invoicing. Journal of International Economics, 105(3), 187-204. https://doi.org/10.1016/j.jinteco.2016.12.011

Eichengreen, B., \& Tong, H. (2015). Effects of renminbi appreciation on foreign firms: The role of processing exports. Journal of Development Economics, 116(4), 146-157. https://doi.org/10.1016/j.jdeveco.2015.04.004

Enders, A., Enders, Z., \& Hoffmann, M. (2018). International financial market integration, asset compositions, and the falling exchange rate pass-through. Journal of International Economics, 110, 151-175. https://doi.org/10.1016/j.jinteco.2017.11.002

Fendoğlu, S., Çolak, M. S., \& Hacıhasanoğlu, Y. S. (2019). Foreign-currency debt and the exchange rate pass-through. Applied Economics Letters, 1-10. https://doi.org/10.1080/13504851.2019.1644423

Frankel, J., Parsley, D., \& Wei, S. J. (2012). Slow pass-through around the world: A new import for developing countries? Open Economies Review, 23(2), 213-251. https://doi.org/10.1007/s11079-011-9210-8

Gaulier, G., Lahrèche-Révil, A., \& Méjean, I. (2008). Exchange-rate pass-through at the product level. Canadian Journal of Economics, 41(2), 425-449. https://doi.org/10.1111/j.1365-2966.2008.00469.x

Gervais, J. P., \& Khraief, N. (2007). Is exchange rate pass-through in pork meat export prices constrained by the supply of live hogs? American Journal of Agricultural Economics, 89(4), 1058-1072. https://doi.org/10.1111/j.1467-8276.2007.01030.x

Goldberg, L. S. (2004). Industry-specific exchange rates for the United States. Economic Policy Review, $5,1-16$.

Goldberg, P. K., \& Knetter, M. M. (1997). Goods prices and exchange rates: what have we learned? Journal of Economic Literature, 35(3), 1243-1272. https://doi.org/10.3386/w5862

Gopinath, G., Gourinchas, P. O., Hsieh, C. T., \& Li, N. (2011). International prices, costs, and mark-up differences. American Economic Review, 101(6), 2450-2486. https://doi.org/10.1257/aer.101.6.2450

Hatzenbuehler, P. L., Abbott, P. C., \& Foster, K. A. (2016). Agricultural commodity prices and exchange rates under structural change. Journal of Agricultural \& Resource Economics, 41(2), 204-224. 
Héricourt, J., \& Poncet, S. (2013). Exchange rate volatility, financial constraints, and trade: Empirical evidence from Chinese firms. The World Bank Economic Review, 29(3), 550-578. https://doi.org/10.1596/1813-9450-6638

Hu, M., Li, Y., Yang, J., \& Chao, C. C. (2016). Actual intervention and verbal intervention in the Chinese RMB exchange rate. International Review of Economics \& Finance, 43, 499-508. https://doi.org/10.1016/j.iref.2016.01.011

Jacob, P., \& Uusküla, L. (2019). Deep habits and exchange rate pass-through. Journal of Economic Dynamics and Control, 115, 67-89. https://doi.org/10.1016/j.jedc.2019.05.011

Josling, T., Anderson, K., Schmitz, A., \& Tangermann, S. (2010). Understanding international trade in agricultural products: One hundred years of contributions by agricultural economists. American Journal of Agricultural Economics, 92(2), 424-446. https://doi.org/10.1093/ajae/aaq011

Kabundi, A., \& Mbelu, A. (2018). Has the exchange rate pass-through changed in South Africa? South African Journal of Economics, 86(3), 339-360. https://doi.org/10.1111/saje.12197

Kabundi, A., \& Mlachila, M. (2019). The role of monetary policy credibility in explaining the decline in exchange rate pass-through in South Africa. Economic Modelling, 79, 173-185. https://doi.org/10.1016/j.econmod.2018.10.010

Kassi, D. F., Sun, G., Ding, N., Rathnayake, D. N., \& Assamoi, G. R. (2019). Asymmetry in exchange rate pass-through to consumer prices: Evidence from emerging and developing Asian countries. Economic Analysis and Policy, 62, 357-372. https://doi.org/10.1016/j.eap.2018.09.013

Law, K. P. J., Satoh, E., \& Yoshimi, T. (2018). Exchange rate pass-through at the individual product level: Implications for financial market integration. The North American Journal of Economics and Finance, 46, 261-271. https://doi.org/10.1016/j.najef.2018.04.011

Li, H., Ma, H., \& Xu, Y. (2015). How do exchange rate movements affect Chinese exports? - A firm-level investigation. Journal of International Economics, 97(1), 148-161. https://doi.org/10.1016/j.jinteco.2015.04.006

Liefert, W. (2009). The transmission of exchange rate changes to agricultural prices (Economic Research Report No 76). United States Department of Agriculture.

Menon, J. (1995). Exchange rate pass-through. Journal of Economic Surveys, 9(2), 197-231. https://doi.org/10.1111/j.1467-6419.1995.tb00114.x

Munir, K., \& Ameer, A. (2018). Effect of economic growth, trade openness, urbanization, and technology on environment of Asian emerging economies. Management of Environmental Quality: An International Journal, 29(6), 1123-1134. https://doi.org/10.1108/MEQ-05-2018-0087

Nakamura, E., \& Zerom, D. (2010). Accounting for incomplete pass-through. Review of Economic Studies, 77(3), 1192-1230. https://doi.org/10.1111/j.1467-937X.2009.589.x

Nguyen, T. N. A., \& Sato, K. (2019). Invoice currency choice, nonlinearities and exchange rate passthrough. Applied Economics, 52(10), 1048-1069. https://doi.org/10.1080/00036846.2019.1650884

Obstfeld, M., \& Rogoff, K. (2000). The six major puzzles in international macroeconomics: Is there a common cause? NBER Macroeconomics Annual, 15(1), 339-390. https://doi.org/10.1086/654423

Persyn, D., \& Westerlund, J. (2008). Error-correction-based cointegration tests for panel data. The STATA Journal, 8(2), 232-241. https://doi.org/10.1177/1536867X0800800205

Rodrìguez-López, J. A. (2011). Prices and exchange rates: A theory of disconnect. Review of Economic Studies, 78(3), 1135-1177. https://doi.org/10.1093/restud/rdq031

Song, M., Zhu, S., Wang, J., \& Zhao, J. (2020). Share green growth: Regional evaluation of green output performance in China. International Journal of Production Economics, 219, 152-163. https://doi.org/10.1016/j.ijpe.2019.05.012

Su, W., Wang, Y., Zhang, C., \& Zeng, S. (2018). The economic effect of cross-border e-commerce technology shocks. Transformations in Business \& Economics, 17(2B), 549-566. 
Wang, S. J., \& Wang, L. (2018). Study on the export effect of China's outward foreign direct investmentan empirical research based on investment intensity and investment breadth. Transformations in Business \& Economics, 17(3C), 379-395.

Westerlund, J. (2007). Testing for error correction in panel data. Oxford Bulletin of Economics and Statistics, 69(6), 709-748. https://doi.org/10.1111/j.1468-0084.2007.00477.x

$\mathrm{Xu}$, J., Du, Q., \& Wang, Y. (2019). Two-sided heterogeneity and exchange rate pass-through. Economics Letters, 183, 108534. https://doi.org/10.1016/j.econlet.2019.108534

Yu, Y., \& Xiao, L. (2017). To accomplish the unaccomplished reform: Lessons and options of RMB Exchange rate reform. China Economist, 12(3), 2.

Yue, Q., Zhang, X., \& Xiang, H. (2018). Mixed oligopoly, foreign penetration, and environmental taxes. Chinese Journal of Population Resources and Environment, 16(1), 77-84.

https://doi.org/10.1080/10042857.2017.1405513 